\title{
IAMJ
}

INTERNATIONAL

AYURVEDIC

MEDICAL JOURNAL

\section{A CASE REPORT ON THE MANAGEMENT OF DUCHENNE'S MUSCULAR DYSTROPHY (DMD) WITH MATRA BASTI}

\author{
Sharayu Kachole', Niranjan Rao ${ }^{2}$, Padmakiran $\mathbf{C}^{3}$ \\ ${ }^{1}$ MD Scholar 3rd Year, ${ }^{2}$ Dean PG \& PhD Studies, HOD, ${ }^{3}$ Associate Professor \\ PG Department of Panchakarma, SDM College of Ayurveda, Udupi, Karnataka, India
}

Corresponding Author: drsharayurk@gmail.com

https://doi.org/10.46607/iamj15p5022021

(Published online: January 2021)

Open Access

(C) International Ayurvedic Medical Journal, India 2021

Article Received:28/01/2021 - Peer Reviewed:02/02/2021 - Accepted for Publication:03/02/2021

Check for updates

\begin{abstract}
Duchenne's Muscular Dystrophy (DMD) is the most common x-linked disorder in children presenting in early childhood due to recessive mutation of the dystrophin gene. It is characterized by progressive weakness in hip and shoulder girdle muscles beginning by age 5. Although there is no absolute cure for DMD, therapies can delay the onset or slow down the progression of disease. Survival beyond the age of 30 years is rare due to the severe chronic complication involving multiple systems. Serum Creatine Phosphokinase (CPK) level determination is the most specific objective parameter for the diagnosis and assessment of severity of Muscular Dystrophy (MD). Based on the presentation of DMD, it can be diagnosed as Mamsavruta Vatal leading to Mamsa Dhatu Upashoshana which is the consequence of Beejabhagavikruti. There will be continuous destruction of Dhatu leading to Vataprakopa again. Hence, the line of management is controlling the Vata and preventing the destruction. The best treatment for it which has this dual action is Matra Basti. With this basic concept, a male child of 10 years diagnosed as Mamsavruta Vata was treated with Matra Basti using Dhanwantara Taila $10 \mathrm{ml} /$ day for about 9 months. As there was associated Sama Doshavastha, Agnichikitsa Lepa was advised for 7 days initially. The treatment showed significant reduction in the level of CPK tested before and after the treatment. Hence, the treatment protocol followed can be taken up for further research and can prove with evidence that, it can be effec-
\end{abstract}


tively practiced in the management of DMD. The long-term benefit, improvement in disease, quality of life can be accessed through the research with long term follow-ups.

Keywords: Duchenne's Muscular Dystrophy, Creatine Phosphokinase, Mamsavruta Vata, Matra Basti, Dhanwantara Taila, Agnichikitsa Lepa

\section{INTRODUCTION}

$\mathrm{DMD}$ is a genetically inherited single-gene pediatric muscle disorder caused by mutations in the DMD gene that proves lethal and affects 1 out of 5000 males born worldwide. Small girls are usually carriers but can be affected in rare cases. Laboratory findings include massive elevations (20-100 x normal) of serum Creatine Phosphokinase, a myopathic pattern on EMG testing and evidence of groups of necrotic muscles fibers with regeneration, phagocytosis and fatty replacement of muscle on biopsy. Owing to the advancement in the genetic diagnostic screening, muscle biopsy is now rarely required. The disease is progressive in nature and leads to symmetrical proximal muscle weakness and wasting. Associated problems include tendon and muscle contractures, progressive kyphoscoliosis, impaired pulmonary function, cardiomyopathy and intellectual impairment. Death by the age of 30 years is commonly seen in affected individuals due to cardiopulmonary failure. For decades, scientists have been trying to find effective treatments for this tragic disease. Current line of management includes physiotherapy and occupational therapy along with steroids. Most advanced strategies include genetic editing and cell-based therapy. Although primarily classified as a muscle disorder, according to recent studies DMD is now also considered as a stem cell disease. DMD mutations result in progressive and irreversible muscle loss in patients, hence the new ongoing research are based on activation of genomically intact muscle stem cells to regenerate muscle fibers.

The identification of serum biomarkers correlating with clinical function and able to anticipate functional scales is particularly needed for personalized patient management. Serum Creatine Phosphokinase (CPK) level is one such parameter which is indicative of the extent of muscle tissue injury seen in DMD. It is pre- sent in significant concentrations in skeletal muscle and cardiac muscle and to a lesser extent in gastrointestinal tract and brain tissue. Destruction of sarcolemma of myofibers leads to release of CPK into the bloodstream which can be estimated on serological examination.

In Ayurveda, the Nidana can be understood under the concept of Matrujabeeja and Beejabhaga Avayavadusti; where, at the time of Garbha formation Meda Adhikyata and Alpata of Shukra in Virya leads to Kha Vaigunya in the Mamsa Dhatu of Garbha. In the later stage, it can be diagnosed as Mamsavruta Vatavyadhi leading to Upashoshana of Mamsa Dhatu explained in the Vatavyadhi Adhyaya by Charakacharya. AvruttaVata causing further Vataprakopa and already existing Kha Vaigunyata leads to Mamsa Dhatu Kshaya thereby exhibiting the symptoms of the disease.The principle of treatment here mainly includes Strotoshodhana and Shamana of Vatadosha in order to arrest the destruction of Dhatu, improving the Bala of Mamsa Dhatu and Rasayana therapy for Dhatu Pushti.

\section{Case Report}

A 10 years old male child presented with complaints of weakness in both lower limbs, difficulty to walk without support, inability to climb stairs without support, frequent falls since 2 years associated with impaired speech, hyperactivity, mental retardation since 9 years.

\section{Detailed history-}

The patient is the only child to non-consanguineous parents and has an uneventful birth history. In 2012 at the age of 3 years, he was diagnosed with Autism Spectrum Disorder with Hypotonic Cerebral Palsy for delayed global development at KMC, Manipal. In 2019, on regular checkup, his doctor noticed his wide based gait and DMD was clinically diagnosed on the 
basis of calf muscle hypertrophy, positive Gower's sign and highly elevated CPK levels (13100 UI/L). EMG showed Myopathic changes and Brain MRI was normal. Further on genetic evaluation, a point mutation in DMD gene was seen that confirmed the diagnosis. He was advised with Physiotherapy, Speech therapy and Occupational therapy. Patient's parents were willing to try Ayurvedic treatment, hence came here for its further management. The progression in the proximal weakness has been gradual and symmetrical. There was no history of muscular pain. Owing to his behavioral and cognitive disability; the patient is dependent of his mother for all his day-to-day activities.

Examination and investigational finding during first visit are given in Table 1, 2

Table 1:General Examination

\begin{tabular}{|l|l|}
\hline Examination (Ayurvedic) & General examination \\
\hline Nadi- 88/min & Pallor- Present \\
\hline Mala- Kathina, Once/ day & Icterus- Absent \\
\hline Mutra- Samyak, 3-4 Vega/ day & Lymph nodes- Not palpable \\
\hline Jivha- Kinchit Saama & Clubbing- Absent \\
\hline Shabda- Gadgad & Oedema- Absent \\
\hline Sparsha- Kinchit Twakrukshata & \\
\hline Druk- Prakruta & \\
\hline Akruti- Krisha & \\
\hline $\begin{array}{l}\text { Sara, Satva, Samhana - Avara } \\
\text { Aharashakti, Vyayamashakti- Hina }\end{array}$ & \\
\hline
\end{tabular}

Table 2:Systemic Examination

\begin{tabular}{|c|c|}
\hline Systemic Examinatio & \\
\hline $\mathrm{CNS}$ & Conscious. Higher mental functions altered. \\
\hline & Cranial Nerves and Sensory- no deficits \\
\hline & Involuntary movements: Absent \\
\hline RS & NVBS Heard \\
\hline CVS & S1S2 Heard \\
\hline $\mathrm{P} / \mathrm{A}$ & Soft and Non tender, No organomegaly \\
\hline $\begin{array}{l}\text { Musculoskeletal Sys- } \\
\text { tem }\end{array}$ & $\begin{array}{l}\text { Inspection- Musculature: Calf muscle Pseudohypertrophy }+ \text {, mild atrophy of Gluteal and thigh mus- } \\
\text { cles. }\end{array}$ \\
\hline & Mild Lumbar lordosis seen \\
\hline & Waddling Gait seen \\
\hline & No muscular twitching, toe walking seen \\
\hline & Palpation- No pain or tenderness in Calf muscles \\
\hline & Muscle Power- 4/5 in all limbs \\
\hline & Tone- Overall Hypotonia \\
\hline & Reflexes- Deep tendon reflexes slightly diminished - Upper extremities and Patella. In- \\
\hline & tact- Achillis reflex, Superficial reflexes \\
\hline & $\begin{array}{c}\text { Signs- Gower sign: Positive } \\
\text { Macroglossia seen }\end{array}$ \\
\hline
\end{tabular}

Investigations done before the treatment-

(21/02/2019) EMG showed myopathic changes.

(21/03/2019) Laboratory tests showed CPK value as $13100 \mathrm{U} / \mathrm{L}$

(26/03/2019) ECHO, MRI Brain showed no significant abnormalities.
(4/05/2019) Genetic evaluation showed hemizygous point mutation at c.200dup.

Haematological test was done at SDM Ayurveda Hospital to assess the present CPK levels on patient's first OPD visit. 
Table 3: CPK Level before treatment

8/1/2020

CPK level

28,610

Diagnosis: Duchenne's Muscular Dystrophy/ Mamsavruta Vata

Intervention-

The patient was admitted in the Hospital on 08/01/2020.

Table 4:Intervention

\begin{tabular}{|c|c|c|c|c|}
\hline \multicolumn{5}{|c|}{ Treatment advised on admission } \\
\hline \multirow[t]{2}{*}{ Panchakarma } & $\begin{array}{l}\text { Agnichikitsa } \\
\text { Lepa }\end{array}$ & $\begin{array}{l}\text { Brihat Agnimantha, Kshudra Ag- } \\
\text { nimantha, Nirgundi, Papata, } \\
\text { Bandha, Tulasi as wet drugs and } \\
\text { Haridra, Maricha, Lashuna, Sar- } \\
\text { shapa and Lavanga in dry form. }\end{array}$ & $\begin{array}{l}\text { External application to } \\
\text { whole body for } 4 \text { hours } \\
\text { for } 7 \text { days. Thickness of } \\
\text { lepa: Ardramahisha- } \\
\text { charma }\end{array}$ & $\begin{array}{l}\text { Laghu, Supachita Ahara } \\
\text { was advised. }\end{array}$ \\
\hline & Matra Basti & $10 \mathrm{ml}$ Dhanvantarataila & $\begin{array}{l}\text { ( } 30 \text { mins after lunch) At } \\
2 \mathrm{pm} \text { for } 7 \text { days. }\end{array}$ & $\begin{array}{l}\text { Average Basti retention } \\
\text { time was } 6 \text { hrs. }\end{array}$ \\
\hline Shamana & $\begin{array}{l}\text { Internal } \\
\text { Medication }\end{array}$ & Aravindasava & $10 \mathrm{ml} \mathrm{BD}$ after food & With lukewarm water \\
\hline
\end{tabular}

On discharge, the patient's mother was trained to administer Matra Basti at home and the following medicines were prescribed for 2 months.

Table 5:Advise on Discharge

\begin{tabular}{|c|c|c|c|c|}
\hline Karma & Matra Basti & $10 \mathrm{ml}$ Dhanvantara Taila/ day for 2 months & $\begin{array}{l}\text { (30 mins after lunch) } \\
\text { At } 2 \mathrm{pm}\end{array}$ & $\begin{array}{l}\text { Laghu, Supachit, Avi- } \\
\text { dahi Ahara }\end{array}$ \\
\hline \multirow[t]{4}{*}{ Shamana } & \multirow{4}{*}{$\begin{array}{l}\text { Internal } \\
\text { Medication }\end{array}$} & Aravindasava & $10 \mathrm{ml} \mathrm{BD}$ after food & With lukewarm water \\
\hline & & Koosmanda Rasayana & 1 tsf BD after food & With lukewarm water \\
\hline & & $\begin{array}{l}\text { Nurod (Contents: Trayodashanga Guggulu, } \\
\text { Brihatvatachintamani, Ashwagandha, Bala, } \\
\text { Kapikacchu, Lashuna, Eranda) }\end{array}$ & $1 \mathrm{OD}$ after food & With lukewarm water \\
\hline & & Saraswatarishta & $10 \mathrm{ml} \mathrm{BD}$ & With lukewarm water \\
\hline
\end{tabular}

\section{RESULT}

The same was continued for a period of 9 months with a periodical follow up. Follow up history is as follows-

Table 6: Follow up and Result

\begin{tabular}{|c|c|c|c|}
\hline Date of follow up & Prescription & Observation (as told by Patient's mother) & Sr CPK value \\
\hline $8 / 01 / 2020$ & & Before admission & $28,610 \mathrm{U} / \mathrm{L}$ \\
\hline $16 / 03 / 2020$ & $\begin{array}{l}\text { 1)Aravindasava } \\
\text { 2) Koosmanda, } \\
\text { Rasayana } \\
\text { 3)Nurod } \\
\text { 4)Saraswatarishta }\end{array}$ & $\begin{array}{l}\text { Patient was able to stand for longer duration than earlier. Try- } \\
\text { ing to communicate through pointing at objects. }\end{array}$ & $10,125 \mathrm{U} / \mathrm{L}$ \\
\hline $20 / 04 / 2020$ & Same as above & $\begin{array}{l}\text { Patient was able to walk for little time without support. Fre- } \\
\text { quency of fall reduced remarkably. }\end{array}$ & - \\
\hline $25 / 05 / 2020$ & Same as above & $\begin{array}{l}\text { Patient's attentiveness improved; communication skills } \\
\text { showed slight improvement. }\end{array}$ & - \\
\hline $14 / 09 / 2020$ & Same as above & $\begin{array}{l}\text { Patient was able to walk without support for longer distance. } \\
\text { Able to communicate about certain demands like food, water. }\end{array}$ & 5920 U/L \\
\hline
\end{tabular}




\section{DISCUSSION}

DMD, a dystrophinopathy due to mutation in the DMD gene located at Xp21 chromosome is the most common childhood onset form of muscular dystrophy that affects males almost exclusively. The prevalence is estimated to be 1 in 3500 to 1 in 5000 live male births. One third of the patients may have various degree of cognitive impairment including learning disability, attention deficit and autistic spectrum disorder. The presenting was one such case. As the disease progresses, additional abnormalities may develop such as scoliosis, contractures, cardiomyopathy, weakness and deterioration of respiratory muscles thereby affecting respiratory function and proving to be a lifethreatening condition with no cure. There have been continuous efforts to improve the diagnosis and to explore therapeutic approaches to treat this fatal disease. Various trials are being conducted on gene replacement therapy, exon skipping therapy, genome modification currently. But it will be long before these therapies get wide acceptance.

The DMD gene regulates the production of dystrophin, a cytoskeletal protein that plays an essential role in maintaining the integrity of cell membrane in skeletal and cardiac muscles cells. Dystrophin is found attached to the inner side of the sarcolemma surrounding the muscles fibres. Mutations in the $D M D$ gene abolish dystrophin expression in both mature muscle fibers and muscle stem cells, causing muscle wasting and satellite cell dysfunction. The body can regenerate and replace some muscle fibers, but over time this rate of regeneration is lost. Creatine Phospho Kinase (CPK) is an enzyme that is found in abnormally high amounts when muscle tissue is damaged. In muscular dystrophy it may raise up to 50 times the upper limit of normal. Other than muscular dystrophies, there are many pathological conditions where CPK is raised. It may also rise in non-pathological causes where muscle injury is possible like strenuous exercise, in athletes, drugs like salicylates, ampicillin etc, multiple IM injections etc.

Pravartana of Cheshta, Sarva Sharira Dhatu Vyuhakara, Sharira Sandhanakara are the Karmas of Prakrita Vatadosha which are disrupted in DMD. Al- so,the Kupita Vatadosha causes various types of Vikaras in the Sharira, Upaghata of Bala and Ayu along with Sarvendriya Upahanti. These are manifested due to Beejabhagaja Dushti and Mithyahara Vihara leading to Avaranajanya Vatavruddhi, Mamsa Dhatu Kshaya, and further Kshayajanya Vataprakopa and Karshya in DMD. Raised CPK level denotes the structural damage to muscle tissue i.e. Mamsa Dhatu Kshaya. Understanding this pathology, it becomes of utmost importance to treat the leading factor i.e. Vataprakopa. Basti being the ultimate line of management for the pacification of Vatadosha and to achieve Balya i.e. Mamsa Dhatu Pushtikara effect, Matra Basti was chosen as ideal in the present case.

Matra Basti is a type of Sneha Basti indicated in the Durbala, Krisha and Vatavyadhi Pidita Vyakti. Being Anapayakari, it can be given for a longer duration without having the need to follow any special Parihara. Due to its less quantity, it stays in Pakwashaya for a longer duration facilitating the absorption of the Sneha to achieve optimal benefit and for the same reason does not cause Sneha Satmyata in the patient. Acharya Charaka while explaining the benefits of regular administration of Matra Basti described it as Balya, Sukhopcharya, Brimhana and Vataroganasha$k a$. The dose of MatraBasti is the Hrisva Matra of Snehapana i.e. the Matra that gets digested within 2 Yaama. Considering that the patient was a 9 years old child, a dose of $10 \mathrm{ml}$ was decided. In the Phalashruti of Dhanwantara Taila, it is said to be Sarvavatarogajeeta and is indicated in Baala, Graha Badha as well as in Ksheena. Hence this Taila was chosen. The action of Matra Basti with Dhanwantara Taila was based upon all the 3 principles of treatments discussed earlier and it showed significant objective improvement in the patient's condition.

Aravindasava have been mentioned in Bhaishajya Ratnavali in Balarogadhikara Prakarana. Considering its Agnideepana, Medhya, Balya and Rasayana properties and special mention of Graharogas in its Phalashruti, this Arishta was prescribed to the patient. Koosmanda Rasayana is Rasayana Yoga with action targeted on Mamsa Dhatu, hence it was prescribed for Mamsa Dhatu Pushti. Saraswatarishta which has Ba- 
kuchi, Ashwagandha and Shatavari as its key ingredients proves to have Medhya and Rasayana properties. The main contents of Nurod tablet are Brihat Vata Chintamani Rasa and Trayodhashanga Guggulu, both of which have been described in Vatavyadhi Prakarana of the Bhaishajya Ratnavali. Along with Vatahara action, their Balya property proved helpful in the management of Mamsavruta Vata.

\section{CONCLUSION}

In progressive degenerative myopathies like DMD, no system of medicine provides a satisfactory treatment. Ayurveda on the other hand does not provide a complete cure but helps to slow down the progression of the disease giving the patient a better chance and quality of life.

\section{REFERENCES}

1. Vaidya Yadavji Trikamji editor, Agnivesha, Charaka Samhita,VatavyadhiChitkitsaAdhyaya, Choukhambha Orientalia, Varanasi, 2011, p 619
2. Pt Hari Sadasiva Shastri Paradakara editor, Vagbhata, Ashtanga Hridaya Samhita, SharirSthana, GarbhavyapatAdhyaya, Chaukhambha Sanskrit Sansthan, Varanasi, 2011, p 383.

3. Ambikadatta Shastri editor, Govind Das, BhaishajyaRatnavali, Vatavyadhi Chikitsa, Chaukamba Sanskrit Sansthan, Varanasi, 1999, p 385.

4. Ambikadatta Shastri editor, Govind Das, BhaishajyaRatnavali, Balaroga Chikitsa, Chaukamba Sanskrit Sansthan, Varanasi,1999, p 755.

5. Dennis L K, Anthony S F, Stephen L H, Dan L L, J Larry J, Joseph L. Harrison's Manual of Medicine, Muscular Dystrophies, McGraw Hill Education, Chennai, 2020, $20^{\text {th }}$ edition, $\mathrm{p} 1089$.

6. Warner E C., Savill's System of Clinical Medicine, Muscular Dystrophy, CBS Publishers \& Distributors Pvt Ltd, New Delhi, 2005, 14 ${ }^{\text {th }}$ edition, $p 1268$.

7. Sun, C., Shen, L., Zhang, Z., \&Xie, X. (2020). Therapeutic Strategies for Duchenne Muscular Dystrophy: An Update. Genes, 11(8), 837. Available at https://doi.org/10.3390/genes11080837-Pubmed
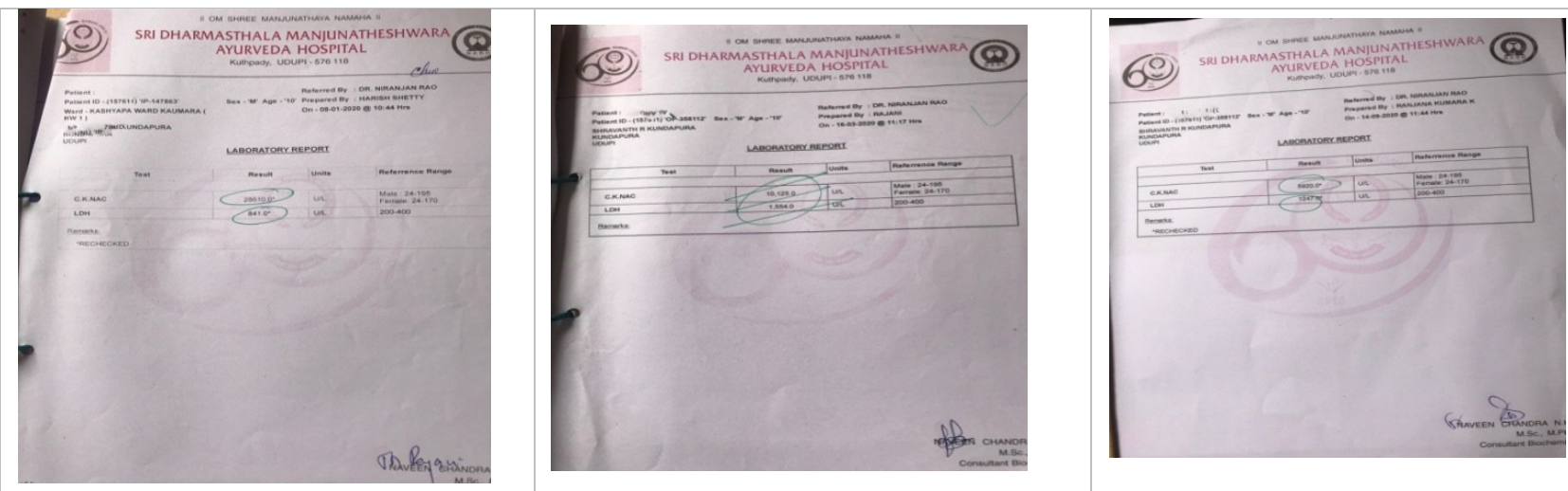

\section{Source of Support: Nil \\ Conflict of Interest: None Declared}

How to cite this URL: Sharayu Kachole et al: A Case Report On The Management Of Duchenne's Muscular Dystrophy (DMD) With Matra Basti. International Ayurvedic Medical Journal \{online\} 2021 \{cited January, 2021\} Available from: http://www.iamj.in/posts/images/upload/2750_2755.pdf 